\title{
sciendo
}

\section{Solutions for Urban Resilience Assessment in Crisis Time}

\author{
Denis-Cătălin ARGHIR \\ Bucharest University of Economic Studies, Bucharest, Romania \\ denis.arghir@ie.ase.ro
}

\begin{abstract}
Cities are complex systems vulnerable to a multitude of risks and disruptions that are becoming increasingly difficult to manage due to urban overcrowding. Socio-economic, technological challenges, but especially natural ones, such as epidemics, have proven to be disruptive from several perspectives of human existence. The negative evolution of the disturbing factors led to the extension of the concept of resilience, traditionally used in socio-ecology, in the urban infrastructure. The aim of this paper is a comparative analysis of some sets of indicators, frameworks, and informatics solutions that can provide an image of how cities can become resilient urban areas. An exploratory analysis is conducted by studying scientific resources and specialized articles that address the issue of developing resilient cities supported by innovation and digital technology. With technology approaches, cities can be helped to prevent and reduce the effects of possible blockages or catastrophes, to respond and intervene promptly in case of crises, and to plan and organize properly in order to recover from shocks or stressors.
\end{abstract}

Keywords: urban resilience, city indicators, crisis, digital solutions, smart city.

\section{Introduction}

Studies conducted by (WorldBank, 2018) show that in 2020, Europe occupies the 3rd place in the ranking of the most urbanized continents, with an urban population of about $75 \%$, and estimates of continuous mobility towards the urban area. According to (McKinsey Global Institute, 2011) forecasts, the world's top 600 cities will concentrate about $20 \%$ of the world's population by 2025 and will produce $60 \%$ of worldwide GDP. Cities are vectors of growth both socially and economically, and in the occurrence of disruptive events, the impact could be major. In addition to intense urbanization, cities are facing an increasing frequency and intensity of hazards and disturbances, exacerbated by climate change and other natural or man-made hazards, putting pressure on urban infrastructure and resources.

Despite these dangers, many cities around the world have not focused enough on developing resilience, especially in developing countries, which are rather facing the problem of providing basic services. Many other cities are in various stages of planning and developing resilience. Some have developed specific resilience plans, others have integrated them into urban development plans or projects defined by a specific sector. Regardless of how it is adopted, the goal is to lead to the construction of a resilient system that is sustainable over time (Dinshaw, 2015).

The context of the last years (January 2007 - January 2018) has shown that the management of risks caused by biological factors has become an international priority, which cannot be postponed regardless of the phase of development of that state, being over 1300 epidemic events, in about 170 countries, in the sights of the (World Health Organization, 2018). Diseases have proven to be disruptive from the perspective of several dimensions of human existence. Outbreaks that have affected the resilience of global communities in recent years - Ebola, MERS-COV, ZIKA, SARS, to which is added the present SARS-COV-2 pandemic affecting communities on all continents (January 2019 - February 2021) being over 110 million diseases, and over 2.4 million deaths, according to (Johns Hopkins University of Medicine, 2021). 
Communities are constantly fighting for the implementation of technologies and the development of real-time analytics solutions with which to monitor and stop the crisis in the field of population health (Patrick, 2020), which is currently taking place, with effects not only in the healthcare field but with an impact on all branches of the economy. The Covid-19 pandemic crisis is an opportunity to rethink how cities will be managed, by carrying out new planning, design, and development projects to protect them in order to be prepared for future emergencies (Chong, 2020). As cities continue to grow, there is an urgent need for comprehensive and holistic approaches to improve cities' resilience to the effects of these disruptions (Latinos \& ICLEI European Secretariat, 2018).

Interest in the concept of resilience in academic literature research increased in the last years. An analysis performed using the keywords" (urban OR city) AND (resilience OR resilient)" on Web of Science returned 10,399 results for various fields related to urban studies (period 1970 - 2020), and 11,551 on Scopus in the same period. There has been a considerable increase in interest in the "urban resilience" topic as depicted in (Figure 1a). The data grouped by area of interest and weighted reveal that the largest number of papers on the Web of Science and Scopus focus on urban studies, urban planning, environmental sciences, social sciences, engineering (Figure 1b,c).


Figure 1. Analysis of articles indexed in academic databases on urban resilience Source: Authors' own representation. (Data source: Web of Science, Scopus).

Numerous researchers have issued various theories about cities from an economic, social, spatial, environmental, and political perspective, aiming at resilience, sustainability, and intelligence; others have made strategic projects to implement the applicability of these concepts. By comparison of conceptualizations of the city appears the hypothesis of discovering quantifiers, either quantitative or qualitative, which can be useful in the assessment of the extent of how cities have developed their abilities to be resilient; but also the mode in which applying innovation and digital technology can enhance city resilience and smartness.

\section{Literature review}

Beginning with 1970, the term "resilience" began to penetrate various fields - ecology, socio-ecology, economics, and later to expand in the study of infrastructure, engineering, computer science, urban, etc.

In the academic literature, (Holling, 1973) was the first to define resilience as the ability of ecosystems to return to their previous state after a period of imbalance; A similar approach was 
had (Pimm, 1984) conceptualizing resilience as "the rapidity of variables to return to equilibrium, following a disturbance". The concept begins to shape another vision in the socio-ecological field, by (Carpenter et al., 2001), as the magnitude of the disturbance of a system that can be tolerated, without changing its structure or functionality, and (Adger, 2000) through the ability of groups or communities to cope with external stresses and disorders as a result of social, political and environmental changes.

Resilience acquires a new approach that presents a perspective of guiding and organizing thinking on the analysis of socio-ecological systems and their sustainable management, in the perspective of (Folke, 2006). In economics, the term is used to identify the speed with which an entity or system can recover from a severe shock to achieve a desired state" (Rose, 2007).

After noticing how the concept of resilience has found its utility in a wide range of socioecological fields (ecology, economy, environmental, and social), the passage of time and the negative evolution of disruptive factors, has led to expansion and infrastructure. The use of the notion has thus been transferred to the field of networks to designate the "critical threshold at which a phase transition from normal state to collapse takes place" (Zeng et al., 2013).

Resilience theory has found its applicability in urban infrastructure since the 2000s, when cities were identified as complex systems (Godschalk, 2003), which can be influenced by various natural, technological, socio-economic hazards, aimed at absorbing disruptions, as well as reorganization to preserve structure, functions and identity (Elmqvist, 2014); (Meerow et al., 2016) consider that there are differences in approach between resilience applied to a disturbance and resilience on a city-wide scale.

Urban planning researches and studies show that resilience to these systems gives cities the ability to absorb disturbances and reorganize during change (Resilience Alliance, 2012), but not only the city's ability to restore essential structures and functions through risk management (United Nations Office for Disaster Risk Reduction, 2009), but moreover their transformation into new entities, with increased powers and a better urban design.

According to (Rockfeller Foundation Arup, 2015), urban resilience represents "the ability of a city's system to survive, adapt, and grow regardless of the types of chronic stresses and acute shocks they experience." By the term urban resilience, (UN-HABITAT, 2018) refers to the capacity of human settlements to resist and recover from multiple risks; (OECD, 2018) examines how resilient cities can increase their sustainable development, well-being, and inclusive growth; ICLEI focuses on emergency identification and assessment and vulnerability reduction (Bizzotto et al., 2019); (URBAN RESILIENCE HUB, 2018) is based on maintaining the continuity of the urban system, regardless of shocks and stresses and on adapting in a positive way, while (C40 Cities, 2017) on understanding and mitigating climate risks for urban infrastructure and services.

\section{Methodological Framework and Research Results}

In this paper, an exploratory analysis is carried out by analyzing the scientific resources that approach urban resilience. To evaluate the existing academic literature on the topic of "urban resilience", it was opted for a bibliometric analysis based on the resulting references from papers on Web of Science. 21 sets of 500 works "Complete Records and Citation References" in tab delimited format were extracted, which was loaded into a software tool for viewing bibliometric networks - "VOSviewer". A map was created based on bibliographic data, for which was opted for the co-citation analysis type and as a unit "cited references". Following the analysis, 6 clusters were extracted, highlighting the nodes with the highest weight in each, representing the works with the most connections. Thus, he identified the most influential studies. The work that represents the 
pioneer in the concept of resilience is of the author - Holling, 1973 - and subsequent works that led to the evolution of the concept towards urban studies.

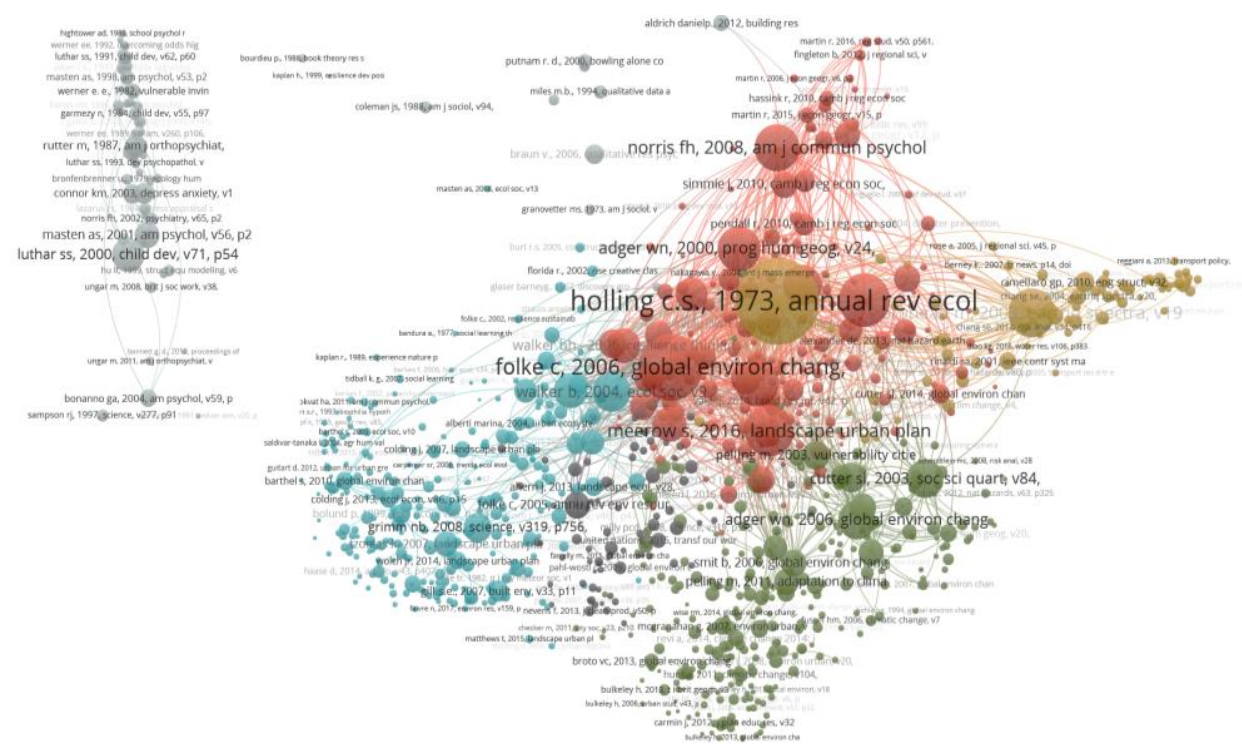

PICBE |

Figure 2. Bibliometric analysis for the Web of Science source

Source: Authors' own research.

For documentation related to indicator systems and informatics solutions, which can help with assessing resilient cities, were analyzed articles published on specialized scientific databases or in various journals, but also a series of urban projects issued by various institutions (UN-HABITAT, ICLEI, ARUP, C40, Urban Resilience Hub, OECD, UNISDR etc.) and was extracted representative indicators and informatics solutions for comparative analysis useful for the improvement of urban resilience.

Each city has a specific architectural composition, with a culture, economy, industry, environment, transport, and public services in which citizens live, work, learn, walk, and carry out various activities, achieving a permanent flow of events (Austria for Integrated Governance in urban areas, 2016). Cities are areas with dense population concentrations, with a prognosis that shows continuous mass urbanization, which in the event of disturbances may become vulnerable.

As cities are affected by various stressors, they will have to cope with an urban resilience plan. In order to build a resilient city, it is necessary to first understand the systems and interdependencies which make up a city, depicted in Figure 3.

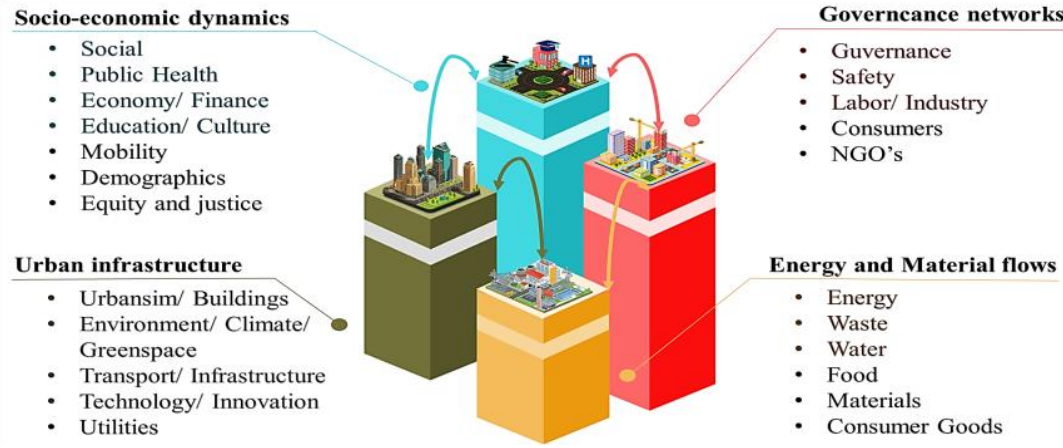

Figure 3. The interdependencies of the urban system

Source: Adapted from (Meerow \& Newell, 2016).

DOI: 10.2478/picbe-2021-0104,pp. 1113-1126, ISSN 2558-9652 |

Proceedings of the $15^{\text {th }}$ International Conference on Business Excellence 2021 
The goal of cities to become resilient, sustainable, smart is to have a promising future for any citizen, to operate simultaneously with them, and does not aim to oversaturate the urban environment with sensors or smart technology, but to meet the pressing needs of citizens (Diancof, 2020), and in case of crises to be able to fully recover, developing increased capacities, ready to face future shocks and stresses.

Table 1. Similarities and differences of the conceptualizations of "city" notion

\begin{tabular}{|c|c|c|c|c|c|c|}
\hline $\begin{array}{c}\text { Urban } \\
\text { concepts }\end{array}$ & $\begin{array}{c}\text { Main } \\
\text { concern }\end{array}$ & Orientation & $\begin{array}{c}\text { Social } \\
\text { capital }\end{array}$ & Planning & $\begin{array}{c}\text { Involved } \\
\text { institutions }\end{array}$ & Vulnerabilities \\
\hline $\begin{array}{l}\text { Resilient } \\
\text { City }\end{array}$ & $\begin{array}{l}\text { Represented } \\
\text { by the ability } \\
\text { to defend, } \\
\text { adapt, and } \\
\text { adjust to } \\
\text { threats and } \\
\text { risks. }\end{array}$ & $\begin{array}{l}\text { Oriented } \\
\text { towards the } \\
\text { improvement } \\
\text { of city systems } \\
\text { through } \\
\text { resident } \\
\text { involvement. }\end{array}$ & $\begin{array}{l}\text { Involvement } \\
\text { of all } \\
\text { stakeholders } \\
\text { to improve } \\
\text { the } \\
\text { perspectives } \\
\text { of the } \\
\text { community } \\
\text { and risk } \\
\text { groups. }\end{array}$ & $\begin{array}{l}\text { Based on } \\
\text { urbanization }\end{array}$ & $\begin{array}{l}\text { Government, } \\
\text { NGOs, } \\
\text { universities, } \\
\text { researchers, } \\
\text { United Nations, } \\
\text { World Bank etc. }\end{array}$ & $\begin{array}{l}\text { It can be affected } \\
\text { by the economic } \\
\text { status and the } \\
\text { geographical } \\
\text { area. }\end{array}$ \\
\hline $\begin{array}{l}\text { Sustainable } \\
\text { City }\end{array}$ & $\begin{array}{l}\text { Represented } \\
\text { by society, } \\
\text { economy, } \\
\text { and } \\
\text { environment, } \\
\text { having the } \\
\text { capability to } \\
\text { respond to } \\
\text { ecological } \\
\text { crises. }\end{array}$ & $\begin{array}{l}\text { Oriented } \\
\text { towards } \\
\text { specific } \\
\text { environmental } \\
\text { and critical } \\
\text { infrastructure } \\
\text { issues through } \\
\text { the } \\
\text { involvement of } \\
\text { authorities and } \\
\text { residents. }\end{array}$ & $\begin{array}{l}\text { Involvement } \\
\text { of all } \\
\text { stakeholders } \\
\text { for economic } \\
\text { well-being } \\
\text { and } \\
\text { environmental } \\
\text { issues. }\end{array}$ & $\begin{array}{l}\text { Based on } \\
\text { urbanization }\end{array}$ & $\begin{array}{l}\text { Government, } \\
\text { NGOs, } \\
\text { environmentalists, } \\
\text { environmental } \\
\text { organizations, } \\
\text { urban planners, } \\
\text { architects, } \\
\text { designers etc. }\end{array}$ & $\begin{array}{l}\text { It can be affected } \\
\text { by low } \\
\text { investment and } \\
\text { lack of } \\
\text { government } \\
\text { involvement. }\end{array}$ \\
\hline $\begin{array}{l}\text { Smart } \\
\text { City }\end{array}$ & $\begin{array}{l}\text { Represented } \\
\text { by the } \\
\text { complex } \\
\text { network of } \\
\text { information } \\
\text { and data } \\
\text { flows. }\end{array}$ & $\begin{array}{l}\text { Oriented } \\
\text { towards } \\
\text { providing } \\
\text { services to } \\
\text { residents } \\
\text { through } \\
\text { e-government. }\end{array}$ & $\begin{array}{l}\text { Involvement } \\
\text { of all } \\
\text { stakeholders } \\
\text { for the } \\
\text { development } \\
\text { of the smart } \\
\text { city. }\end{array}$ & $\begin{array}{l}\text { Based on } \\
\text { information } \\
\text { and } \\
\text { communication } \\
\text { technology }\end{array}$ & $\begin{array}{l}\text { Government, } \\
\text { universities, } \\
\text { researchers, } \\
\text { municipality, civil } \\
\text { society, private } \\
\text { sector, } \\
\text { entrepreneurs, } \\
\text { public service } \\
\text { providers, United } \\
\text { Nations, } \\
\text { European Union } \\
\text { etc. }\end{array}$ & $\begin{array}{l}\text { It can affect } \\
\text { privacy } \\
\text { surveillance, lack } \\
\text { of } \\
\text { confidentiality, } \\
\text { lack of access to } \\
\text { technological } \\
\text { support, cyber- } \\
\text { attacks (hacking, } \\
\text { terrorism). }\end{array}$ \\
\hline
\end{tabular}

Source: Adapted from (Hatukaa et al., 2018).

\section{Study of systems of indicators for assessing urban resilience}

Indicator systems are characteristics that can be used to evaluate a city through a qualitative description or quantitative metrics. Metrics are specific values that can describe the indicators, and with their help, the progress over time can be measured and illustrate the status of any given indicator. 
To evaluate, monitor, and assist in the development of effective policies to improve the resilience of cities, indicator systems are defined and used (Figueiredo et al., 2018). The indicator, as a tool for assessing resilience, helps to identify vulnerabilities and risks; as an information tool, helps to design early warning systems and make emergency response plans; as a monitoring tool, identifies how well the city is prepared to respond and recover from disasters and shocks (Landry et al., 2018).

Studying the specialized literature and urban projects, a series of indicators adopted either globally or regionally were highlighted, meant to evaluate various aspects of urban resilience involving innovation and digital technology, from which they were analyzed 6:

One set of indicators are those from (100 Resilient Cities, ARUP and Rockefeller Foundation, 2015), which propose "City Resilience Framework". This describes the fundamental results of a resilient city. It was designed using 150 literature sources, studies from 14 cities (Bristol City Council, 2015). It is structured in 4 categories: health and welfare, urban systems and services, economy, and society, leadership, and strategy; it proposes 12 objectives to which a number of important qualities are assigned - flexibility, redundancy, robustness, ability, reflexivity, inclusiveness, and integration, as well as 52 indicators for determining strengths and establishing weaknesses, to measure the evolution of city performance over time, but also to reduce the strong impact of possible disturbances.

Another series of significant indicators are those standardized internationally by the International Organization for Standardization, relevant indicators for smart cities - "ISO 37122" and resilient cities - "ISO 37123" (ISO, 2019). In the development of these standards, 8 pilot cities were studied, which helped to establish over 30 indicators, which aim to achieve a series of criteria: completeness, technological neutrality, simplicity, validity, verifiability, and availability). With the help of these indicators, cities can compare (WCCD, 2018) their performance and change good practices.

The "CITYkeys Index" was designed within a European Union project - HORIZON 2020, in order to develop indicators for determining the performance, monitoring, and harmonized comparison of European cities' initiatives during the project implementation of smart solutions. They include 4 main themes - people, planet, prosperity, and governance and are focused on developing a smart city that aims to improve community life, reduce resource consumption, build a thriving green economy, and foster a well-developed local democracy and 76 indicators focused on evaluating the evolution and development of a smart city (Bosch et al., 2017).

China is one of the most important countries fighting for urban sustainability, due to its excessive urban population, which is expected to reach 1 billion by 2030 (McKinsey and Company et al., 2010). Therefore, there is a need for the "China Urban Sustainability Index", designed to develop the relative performance of cities over time. For the evaluation, 185 cities of various sizes were chosen, for which 23 resilience indicators were developed, which measure performance in relation to 4 essential aspects: economy, society, resources, and environment (The Urban China Initiative, 2017).

"The ranking for medium-sized Smart Cities" project was developed to support mediumsized cities and is based on a set of indicators that allow the development of perspectives for development and the identification of strengths and weaknesses (Giffinger et al., 2007). Within the project, 6 categories are proposed in which the indicators are grouped (smart economy, smart people, smart governance, smart mobility, smart environment, smart living). Each of these categories contains 31 factors, which is the framework for the 74 performance indicators of a city as a smart city. The project was applied to 77 cities around the world. 
Another indicator for measuring the city's performance is "Key performance indicators for Smart Sustainable Cities", also designed by the European Union to encourage the use of information technology to facilitate the transition to smart and sustainable cities, by integrating existing international standards and key performance indicators (United Nations Economic Commission for Europe, 2016). The indicators, numbering 71, are structured according to the area, subject, and typology and correspond to 3 dimensions - economy, environment, society, and culture, being identified 6 major topics for each, to which the indicators are assigned.

Through the comparative analysis undertaken in the research, the indicators were regrouped in one of the 4 major categories corresponding to the interdependencies of the urban system, and are represented in Table 2.

Table 2. Comparative study of the sets of indicators used in the context of resilient smart cities

\begin{tabular}{|c|c|c|c|c|c|c|c|c|c|c|c|c|c|c|c|c|c|c|}
\hline \multirow{2}{*}{\begin{tabular}{|c|} 
\\
\\
Framework \\
Organization \\
that promotes
\end{tabular}} & \multicolumn{4}{|c|}{$\begin{array}{c}\text { Socio-economic } \\
\text { dynamics }\end{array}$} & \multicolumn{4}{|c|}{$\begin{array}{c}\text { Urban } \\
\text { infrastructure }\end{array}$} & \multicolumn{3}{|c|}{$\begin{array}{c}\text { Governance } \\
\text { network }\end{array}$} & \multicolumn{4}{|c|}{\begin{tabular}{|c|} 
Energy and \\
material flows \\
\end{tabular}} & \multirow[b]{2}{*}{ Purpose } & \multirow[b]{2}{*}{$\begin{array}{c}\text { Number } \\
\text { of indicators }\end{array}$} & \multirow[b]{2}{*}{$\begin{array}{l}\text { Date of the } \\
\text { latest version/ } \\
\text { Countries that } \\
\text { have adopted }\end{array}$} \\
\hline & 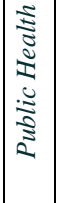 & 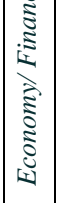 & 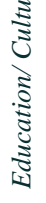 & $\begin{array}{l}\vec{Z} \\
\tilde{U} \\
\tilde{D}\end{array}$ &  & 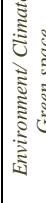 &  & 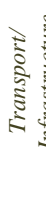 &  & $\frac{\overrightarrow{3}}{\overrightarrow{2}}$ & 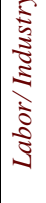 & 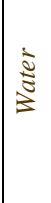 & $\begin{array}{l}5 \\
5 \\
5 \\
3 \\
1\end{array}$ & \begin{tabular}{|} 
के \\
$\grave{2}$ \\
过
\end{tabular} & $\frac{5}{\frac{5}{2}}$ & & & \\
\hline $\begin{array}{l}\text { City Resilience } \\
\text { Framework } \\
\text { Arup; } \\
\text { Rockefeller Foundation } \\
\end{array}$ & $x$ & $\mathrm{X}$ & $X$ & $X$ & $X$ & $X$ & $X$ & $X$ & $X$ & $X$ & $X$ & X & $X$ & $X$ & $X$ & $\begin{array}{l}\text { Fundamental } \\
\text { indicators of a } \\
\text { resilient city }\end{array}$ & $\begin{array}{l}4 \text { categories; } \\
12 \text { objectives; } \\
52 \text { indicators; } \\
156 \text { variables. }\end{array}$ & \begin{tabular}{|l|}
2015 \\
Global
\end{tabular} \\
\hline $\begin{array}{l}\text { International } \\
\text { Standard } \\
\text { ISO } 37123 \\
\text { International } \\
\text { Organization for } \\
\text { Standardization } \\
\end{array}$ & $X$ & $\mathrm{X}$ & $X$ & $X$ & & $X$ & & $X$ & & $X$ & & $X$ & $X$ & $\mathrm{X}$ & $X$ & $\begin{array}{l}\text { Indicators for city } \\
\text { services and } \\
\text { quality of life - } \\
\text { Indicators for } \\
\text { resilient cities }\end{array}$ & $\begin{array}{l}19 \text { categories; } \\
9 \text { objectives; } \\
30 \text { base } \\
\text { indicators } \\
\text { available. }\end{array}$ & \begin{tabular}{|l|}
2018 \\
Global
\end{tabular} \\
\hline $\begin{array}{l}\text { CITY keys } \\
\text { Index } \\
\text { European Union - } \\
\text { HORIZON } 2020 \\
\text { Program }\end{array}$ & $\mathrm{X}$ & $\mathrm{X}$ & $X$ & $X$ & $X$ & $X$ & $X$ & $X$ & $X$ & $X$ & & $X$ & $X$ & $\mathrm{X}$ & $X$ & $\begin{array}{l}\text { Indicators for } \\
\text { determining } \\
\text { performance, } \\
\text { monitoring and } \\
\text { harmonized } \\
\text { comparison of } \\
\text { smart city } \\
\text { initiatives }\end{array}$ & $\begin{array}{l}4 \text { categories; } \\
4 \text { objectives; } \\
99 \text { project } \\
\text { indicators; } \\
76 \text { city } \\
\text { indicators. }\end{array}$ & \begin{tabular}{|l|}
2017 \\
European
\end{tabular} \\
\hline $\begin{array}{l}\text { China Urban } \\
\text { Sustainability } \\
\text { Index } \\
\text { Urban China Initiative }\end{array}$ & $x$ & $\mathrm{X}$ & $X$ & $X$ & & X & & $X$ & & & $X$ & X & $X$ & $X$ & & \begin{tabular}{|l|} 
Indicators for \\
measuring \\
environmental \\
resilience and \\
efficiency of urban \\
resources \\
\end{tabular} & $\begin{array}{l}4 \text { categories; } \\
21 \text { indicators. }\end{array}$ & \begin{tabular}{|l|}
2017 \\
China
\end{tabular} \\
\hline $\begin{array}{l}\text { The ranking for } \\
\text { medium-sized } \\
\text { Smart Cities } \\
\text { Vienna Regional } \\
\text { Science Center }\end{array}$ & $\mathrm{X}$ & $\mathrm{X}$ & $X$ & $X$ & $X$ & $X$ & X & $X$ & $X$ & X & $X$ & X & & $\mathrm{X}$ & $X$ & $\begin{array}{l}\text { Indicators for the } \\
\text { development of } \\
\text { medium-sized } \\
\text { smart cities }\end{array}$ & $\begin{array}{l}6 \text { categories; } \\
31 \text { factors; } \\
74 \text { indicators. }\end{array}$ & \begin{tabular}{|l|}
2015 \\
European
\end{tabular} \\
\hline $\begin{array}{l}\text { Key performance } \\
\text { indicators for } \\
\text { Smart Sustainable } \\
\text { Cities } \\
\text { United Nations } \\
\text { Economic Commission } \\
\text { for Europe }\end{array}$ & $\mathrm{X}$ & $\mathrm{X}$ & $X$ & $X$ & & $X$ & X & & & X & $X$ & X & & $\mathrm{X}$ & $X$ & $\begin{array}{l}\text { Indicators for } \\
\text { measuring the } \\
\text { performance, } \\
\text { sustainability, and } \\
\text { smartness of the } \\
\text { city }\end{array}$ & $\begin{array}{l}3 \text { categories; } \\
18 \text { major } \\
\text { subjects; } \\
71 \text { indicators. }\end{array}$ & \begin{tabular}{|l|}
2015 \\
European
\end{tabular} \\
\hline
\end{tabular}

Source: Authors' own research. 
By the analysis, it was found that indicators respect the objective of the measurement, the attributes related to the smart resilient city are highlighted, some studies explicitly specify the weights for each indicator and the aggregation method, and others leave to the discretion of those entitled to apply them.

Finding relevant indicators for specific urban contexts can help build sustainable urban development, contribute to the resilience, sustainability, and intelligence of strategies, programs, projects, and services carried out under the direct responsibility of communities, can participate in cross-sectorial, multidisciplinary approaches, increase the efficiency and attractiveness of communities (Fitsilis, 2018). In order to apply such indicators at the level of a county or city, the measurements could indicate the current level and monitor the progress of resilience in terms of the 4 dimensions (interdependence) of urban systems taken into account in this analysis. They allow the comparison of performance between different counties/ cities. They are also useful after the occurrence of disturbing events, for evaluating the levels at which they are located after the application of countermeasures, depicted in Figure 4.

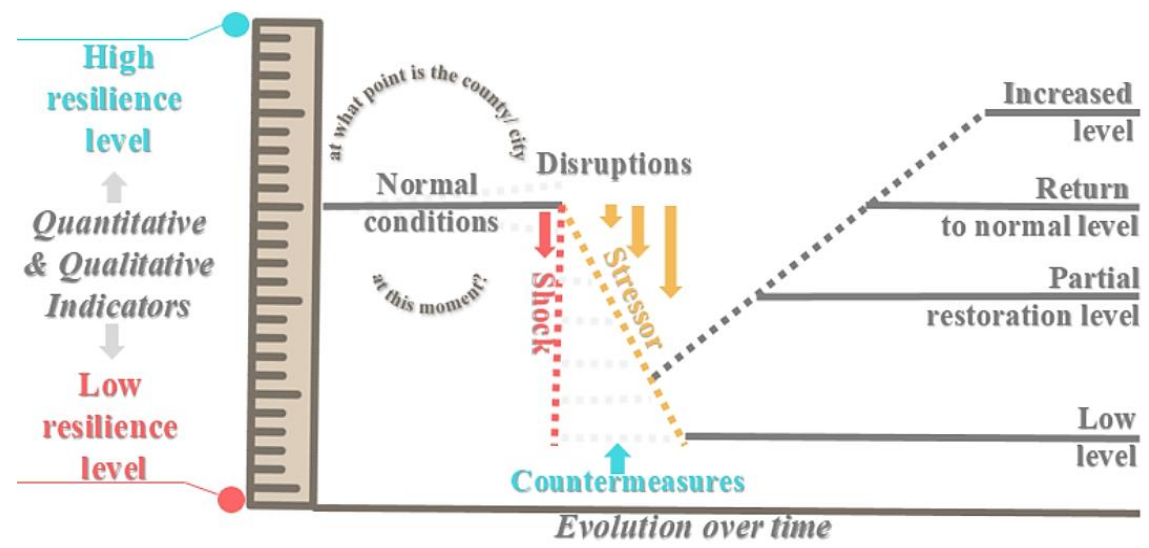

Figure 4. Assessment of the resilience level

Source: Adapted from (Conway et al., 2010).

It can be concluded that although there are ticked a large part of the sub-dimensions, at the level of the analyzed frameworks, each covers only a small part of the sub-dimension issue, each with a specific characteristic, which can be a starting point for achieving own indicators adapted for the cities/ counties for which will be performed such an evaluation - both to obtain an aggregate score at the level of each dimension, and a general one.

\section{Limits of indicator systems}

Data aggregation - indicators use quantitative values to facilitate data aggregation and compatibility over time; they allow the establishment of targets for improving performance, and for those that cannot be measured quantitatively, they are evaluated qualitatively using an ordinal scale; most indices have different units, which must be converted to an equivalent scale without units before applying weights.

Results interpretation - there is required caution in interpreting the results of performance assessment and ensuring that they are context-specific. Some indicator frameworks address this issue by setting objectives or criteria based on good practice.

Data availability - is a challenge for measuring performance, there are various limitations, which can be overcome by the following approaches: 
- The values of the indicators could be redefined using the currently existing data, keeping the intention of the indicator or at least a proxy for the indicator.

- Complementary ways to obtain data can be used, from passive techniques such as surveys to the creation and use of intelligent informatics solutions to facilitate data capture and analysis.

\section{Informatics solutions for assessing urban resilience}

Smart systems aim to create a smart infrastructure for cities, using innovations in data analysis and information and communication technology (ICT). They help, thanks to their ability to collect and provide data and information, both to the administrative department to develop more viable strategies and better public services, and to the private environment (Abdulaziz et al., 2018).

In the heart of the smart, resilient city should be found cyber systems that continuously collect amounts of data from various sources and use them to improve planning, modernize infrastructure, and provide better services. The common elements can be observed in all scientific theories and projects put into practice, ICT being the basis that facilitates smart development, taking into account the pillars of sustainability, resilience, governance, and well-being of citizens (Sabou et al., 2019).

Studying the literature related to informatics solutions, either currently applied in different cities, or in the design stage, it is observed that there are various levels that have been taken into account, either in terms of the topic it aims at, either of the technologies used, represented in Table 3.

Table 3. Comparative study of useful informatics solutions for city resilience assessment

\begin{tabular}{|c|c|c|c|c|}
\hline Tool & $\begin{array}{c}\text { Proposed } \\
\text { by }\end{array}$ & Applicable & $\begin{array}{l}\text { Description / } \\
\text { Technologies }\end{array}$ & Conclusion \\
\hline \multirow[t]{2}{*}{$\begin{array}{l}\text { Europe } \\
\text { Smart City } \\
\text { Model }\end{array}$} & \multirow[t]{2}{*}{$\begin{array}{l}\text { Vienna } \\
\text { University } \\
\text { of } \\
\text { Technology } \\
(2014)\end{array}$} & \multirow[t]{2}{*}{$\begin{array}{l}\text { European; } \\
\text { implemented } \\
\text { in } 77 \text { cities } \\
\text { worldwide; } \\
\text { Medium- } \\
\text { size cities; }\end{array}$} & $\begin{array}{l}\text { - Implements weight factors and indicators from } \\
\text { "The project for ranking medium-sized smart } \\
\text { cities" framework; } \\
\text { - Are used in the qualitative determination of the } \\
\text { characteristics of indicators and for the } \\
\text { quantitative calculation of the weight for the } \\
\text { urban classification; } \\
\text { - Various directions can be drawn to guide intelligent } \\
\text { development (Giffinger, 2014). }\end{array}$ & \multirow[t]{2}{*}{$\begin{array}{l}\text { - Useful tool due to } \\
\text { the possibility of } \\
\text { comparing some } \\
\text { cities with others } \\
\text { similar in } \\
\text { population or size, } \\
\text { in the perspective } \\
\text { of strengths and } \\
\text { weaknesses; }\end{array}$} \\
\hline & & & On-line solution based on indicators & \\
\hline \multirow[t]{2}{*}{$\begin{array}{l}\text { Quick } \\
\text { Response } \\
\text { Estimator } \\
\text { Tool }\end{array}$} & \multirow[t]{2}{*}{$\begin{array}{l}\text { United } \\
\text { Nations } \\
\text { Office for } \\
\text { Disaster } \\
\text { Risk } \\
\text { Reduction } \\
\text { (UNDRR, } \\
\text { 2019) }\end{array}$} & \multirow[t]{2}{*}{ Global } & $\begin{array}{l}\text { - It is used to identify and understand present and } \\
\text { future risks, stresses, shocks, and threats, both for } \\
\text { people and physical assets, to achieve resilient } \\
\text { cities; } \\
\text { - The tool includes hazard indicators, aligned with } \\
10 \text { key elements for creating a resilience score } \\
\text { (e.g.: "Increasing infrastructure resilience", "Fast } \\
\text { recovery and better reconstruction" etc. (UNISDR, } \\
\text { 2015); } \\
\text { - Identifies the "most probable" and "most serious" } \\
\text { risk scenarios of natural hazards in diverse areas } \\
\text { (e.g.: geophysics, meteorology, climatology, } \\
\text { biology) which can affect } 4 \text { vulnerable categories: } \\
\text { infrastructure, productive sector, essential } \\
\text { services, human or social aspects. }\end{array}$ & \multirow[t]{2}{*}{$\begin{array}{l}\text { - Tool that helps to } \\
\text { create an overview } \\
\text { of the } \\
\text { vulnerability and } \\
\text { risks that must be } \\
\text { taken into account } \\
\text { to increase the } \\
\text { resilience of the } \\
\text { city against } \\
\text { hazards. }\end{array}$} \\
\hline & & & On-premise solution based on indicators & \\
\hline
\end{tabular}




\begin{tabular}{|c|c|c|c|c|}
\hline Tool & $\begin{array}{c}\text { Proposed } \\
\text { by }\end{array}$ & Applicable & $\begin{array}{l}\text { Description / } \\
\text { Technologies }\end{array}$ & Conclusion \\
\hline \multirow[t]{2}{*}{$\begin{array}{l}\text { Disaster } \\
\text { Resilient } \\
\text { Smart City }\end{array}$} & \multirow[t]{2}{*}{$\begin{array}{l}\text { (Shah et al., } \\
\text { 2019) }\end{array}$} & \multirow[t]{2}{*}{$\begin{array}{l}\text { Stage } \\
\text { Project } \\
\text { (tested at } \\
\text { micro level) }\end{array}$} & $\begin{array}{l}\text { - Aims to generate early warnings and monitoring } \\
\text { in case of emergencies using data analysis; } \\
\text { - The project envisages } 3 \text { major incidents that can } \\
\text { occur in various situations, taking for analysis a } \\
\text { building and not an entire city; } \\
\text { - The studied events are: fires (monitoring the } \\
\text { density of smoke in the building), the increasing } \\
\text { the level of pollution (monitoring the } \\
\left.\text { concentration of } \mathrm{CO}, \mathrm{SO}_{2}, \mathrm{NO}_{2}\right) \text {, and the } \\
\text { identification of possible traffic jams (caused by } \\
\text { natural disasters or accidents and emergency } \\
\text { evacuation). }\end{array}$ & \multirow[t]{2}{*}{$\begin{array}{l}\text { - This tool is a } \\
\text { valuable starting } \\
\text { point in terms of } \\
\text { applied } \\
\text { technologies in the } \\
\text { design and } \\
\text { collection of data, } \\
\text { but does not help } \\
\text { to predict and } \\
\text { recover from } \\
\text { disasters in the } \\
\text { current phase. Is } \\
\text { not reliable at the } \\
\text { macro level. }\end{array}$} \\
\hline & & & Big Data, IoT, Hadoop, Map Reduce, HDFS, Spark & \\
\hline \multirow[t]{2}{*}{$\begin{array}{l}\text { Smart Digital } \\
\text { City }\end{array}$} & \multirow[t]{2}{*}{$\begin{array}{l}\text { (Rathore et } \\
\text { al., 2017) }\end{array}$} & \multirow[t]{2}{*}{$\begin{array}{l}\text { Stage } \\
\text { Project } \\
\text { (tested at } \\
\text { micro level) }\end{array}$} & $\begin{array}{l}\text { - Considers a resilient approach, with the help of } \\
\text { IoT devices, by collecting substantial amounts of } \\
\text { data about the city and analyzing them to guide } \\
\text { the authorities towards a smarter and more digital } \\
\text { city; } \\
\text { - The data is collected from various intelligent } \\
\text { systems (e.g.: houses, smart parking, road traffic } \\
\text { surveillance and monitoring systems, temperature } \\
\text { measurement sensors) to generate alerts and to } \\
\text { react in case of emergency }\end{array}$ & \multirow[t]{2}{*}{$\begin{array}{l}\text { - Proposes the } \\
\text { construction of a } \\
\text { centralized } \\
\text { analysis system } \\
\text { and integration in } \\
\text { a data center to } \\
\text { allow decision } \\
\text { making. } \\
\text { - It is similar to } \\
\text { Disaster Resilient } \\
\text { Smart City } \\
\text { project. }\end{array}$} \\
\hline & & & $\begin{array}{l}\text { Big Data, IoT, Hadoop, Map Reduce, HDFS, Spark, } \\
\text { Machine Learning, Decision Models }\end{array}$ & \\
\hline \multirow[t]{2}{*}{$\begin{array}{l}\text { Social Media } \\
\text { for } \\
\text { Improving } \\
\text { Disaster } \\
\text { Management } \\
\text { Process }\end{array}$} & \multirow[t]{2}{*}{$\begin{array}{l}\text { (Shah et al., } \\
\text { 2017) }\end{array}$} & \multirow[t]{2}{*}{$\begin{array}{l}\text { Application } \\
\text { (tested at } \\
\text { micro level) }\end{array}$} & $\begin{array}{l}\text { - Proposes a real-time, updated and filtered data } \\
\text { delivery framework extracted from social } \\
\text { networks, and also a web user API for structured } \\
\text { and real-time defined data entries, available to } \\
\text { citizens, administrative and emergency services or } \\
\text { NGO's. }\end{array}$ & \multirow[t]{2}{*}{$\begin{array}{l}\text { - Provides } \\
\text { structured and } \\
\text { reliable data for } \\
\text { real-time disaster } \\
\text { management } \\
\text { systems and } \\
\text { spatial distribution } \\
\text { exploration. } \\
\text { - The API and } \\
\text { framework can } \\
\text { work together to } \\
\text { produce } \\
\text { information for a } \\
\text { disaster } \\
\text { management } \\
\text { system. }\end{array}$} \\
\hline & & & GIS, Social Media System & \\
\hline
\end{tabular}

Source: Authors' own research.

Informatics solutions help to develop viable systems in the direction of developing smart resilient cities by including both indicators appropriate to the city context and modern technology. Those support data acquiring and mining to identify the immediate impact of crises (Reveiu and Arghir, 2020), access to data storage and retrieval infrastructure, the selection of data processing services, visualization and analysis from various devices connected to the Internet network, and the effective use of the provided results.

\section{Conclusion}

The comparison of the indicator frameworks revealed that each aims at certain goals. Even if there is a similarity between the themes targeted by the indicators, the sub-indicators prove to be specific 
to each framework. To assess the degree of urban resilience, an aggregate set of indicators could be designed based on the study of several frameworks, or the implementation of frameworks as defined. For all selected indicators, data will need to be obtained from the authorities of the city involved in the evaluation, either from open data sources or official statistics. The currently developed indicators compare either the progress of cities over time or their performance in relation to other similar urban areas, in order to provide a consistent or standardized method of data collection and efficiency measurement, on the way to becoming a smarter and more resilient city.

It is found that not only the measurement of indicators can contribute to urban resilience. Recent advances show that modern technologies can play an important role, such as data analysis technology and the Internet of Things, as they provide an opportunity for the development of resilience environments for smart resilient cities. Their combination with Big Data processing environments can develop an efficient environment for real-time and offline analysis, which helps to collect large volumes of data sets from various sources - traffic simulators, smart buildings, social networks, sensors etc.

The current context of the crisis caused by the Covid-19 pandemic could be a good time for all those entitled to adopt an openness to a much more robust resilience plan. This should be based on both indicators and informatics solutions and centered on crises with potential to unbalance urban systems, in order to avoid collapse, but moreover, the total recovery and with increased capacities.

The extension of the research will consist in building a solution that will be based on indicators selected from various frameworks, as well as built on the data available at the level of urban communities at the level of which the resilience assessment will be applied. In addition to the indicators, real-time captured data will be included, which can provide a dynamic picture of the effects of possible crises.

\section{Acknowledgement}

This paper was co-financed by The Bucharest University of Economic Studies during the PhD program.

\section{References}

100 Resilient Cities, ARUP, \& Rockefeller Foundation (2015). City Resilience Framework, 3-21.

Abdulaziz, A., Tipper, D., \& Kelly-Pitou, K. (2018). Locating Microgrids to Improve Smart City Resilience, Resilience Week, Resilient Pittsburgh.

Adger, W.N. (2000). Social and ecological resilience: are they related?, Progress in Human Geography, 1-6.

Austria for Integrated Governance in urban areas. (2016). Smart City Monitor - New Information Technology for Municipalities and Citizens, Retrieved 06 14, 2020.

Bizzotto, M., Huseynova, A., \& Estrada, V. (2019). Resilient cities, thriving cities: the evolution of urban resilience, ICLEI Local Governments for Sustainability, p. 5.

Bosch, P., Neumann, H.-M., Rovers, V., \& Airaksinen, M. (2017, 01 24). CITYkeys indicators for smart city projects and smart cities. Uniunea Europeana - Horizon 2020, 6-306, Retrieved from CITYkeys indicators for smart city projects and smart cities.

Bristol City Council, 100 Resilient Cities, \& Arup (2015, 11). Preliminary Resilience Assessment, 8-37. 
C40 Cities (2017). Resilience. Retrieved 2020, from https://www.c40.org/tags/resilience.

Carpenter, S., Walker, B., Anderies, J. M., \& Abel, N. (2001). From metaphor to measurement: Resilience of what to what?, Ecosystems, 4(8), 765-781.

Chong, B. (2020). Five city resilience lessons from the coronavirus, Retrieved 01 18, 2021, from ARUP: https://www.arup.com/perspectives/five-city-resilience-lessons-from-coronavirus

Conway, G., Waage, J., \& Delaney, S. (2010). Science and Innovation for Development, UK Collaborative on Development Sciences - UKcds, 308-313.

Diancof, L. (2020, April 14). Cetățeanul Inteligent vs. Pandemia de COVID-19, Retrieved January 7, 2021, from Asociatia Romana pentru Smart City, https://romaniansmartcity.ro/ cetateanul-inteligent-vs-pandemia-de-covid-19/.

Dinshaw, A. (2015, June 10). Three Enabling Factors for Building Urban Resilience, Retrieved 02 01, 2021, from The City Fix: https://thecityfix.com/blog/thre-enabling-factors-for-building -urban-resilience-ayesha-dinshaw/.

Elmqvist, T. (2014). Urban resilience thinking, Solutions, 5(5), 26-30.

Figueiredo, L., Honiden, T., \& Schumann, A. (2018, 02). Indicators for Resilient Cities, OECD Regional Development Working Papers.

Fitsilis, P. (2018). Standards for Smart and Sustainable Cities, Smart Statistics 4 Smart Cities, 4-36.

Folke, C. (2006). Resilience: The emergence of a perspective for, Global Environmental Change, $1-8$.

Giffinger, R. (2014, 11 09). European Smart Cities - Benchmarking, Retrieved 2020, from http://www.smart-cities.eu/?cid=5\&city=47\&ver=3

Giffinger, R., Kalasek, R., Fertner, C., \& Pichler Milanović, N. (2007, 10). Smart cities - Ranking of European medium-sized cities, Research Institute for Housing, Urban and Mobility Studies (OTB), 8-22.

Godschalk, D. (2003). Urban Hazard Mitigation: Creating Resilient Cities, Natural Hazards.

Hatukaa, T., Rosen-Zvi, I., Birnhack, M., Toch, E., \& Zur, H. (2018, 04 16). The Political Premises of Contemporary Urban Concepts: The Global City, the Sustainable City, the Resilient City, the Creative City, and the Smart City, Planning Theory \& Practice, p. 4.

Holling, C.S. (1973). Resilience and stability of ecological systems, Annual Review of Ecology and Systematics, 1-23.

ISO (2019). ISO 37123:2019 - Sustainable cities and communities - Indicators for resilient cities, Retrieved 01 14, 2021, from ISO, https:/www.iso.org/standard/70428.html.

Johns Hopkins University of Medicine. (2021, 02). Covid-19 Dashboard by CSSE at Johns Hopkins University of Medicine, Retrieved 01 31, 2021, from Coronavirus Resource Center, https://coronavirus.jhu.edu/map.html.

Landry, J.-N., Webster, K., Wylie, B., \& Robinson, P. (2018). How can we imporve urban resilience with open data?, Open Data Institute.

Latinos, V., \& ICLEI European Secretariat. (2018). Smart Mature Resilience, European Resilience Management Guidline, p. 5.

McKinsey \& Company, Columbia University, \& Tsinghua University,. (2010, 11). The Urban Sustainability Index:A New Tool for Measuring China's Cities, The Urban China Initiative, 6-17.

McKinsey Global Institute (2011). Urban world: Mapping the economic power of cities, Retrieved 02 01, 2021, from McKinsey \& Company, https://www.mckinsey.com/featured-insights/ urbanization/urban-world-mapping-the-economic-power-of-cities. 
Meerow, S., \& Newell, J. (2016). Urban resilience for whom, what, when, where, and why?, Urban Geography, 8.

Meerow, S., Newell, P., \& Stults, M. (2016). Defining urban resilience: A review, Landscape and Urban Planning.

OECD (2018). Resilient Cities. Retrieved 05 15, 2020, from https://www.oecd.org/cfe/regionalpolicy/resilient-cities.htm.

Patrick, J. (2020, March 18). Ce trebuie să știi despre COVID-19 și Smart City, Retrieved 0210 , 2021, from Asociatia Romana pentru Smart City, https://romaniansmartcity.ro/ce-trebuiesa-stii-despre-covid-19-si-smart-city/.

Pimm, S. (1984). The complexity and stability of ecosystems, Nature 30 7(5949), 321-326.

Rathore, M., Anand , P., Won-Hwa, H., Imtiaz , A., \& Sharjil , S. (2017, 12 30). Exploiting IoT and big data analytics: Defining Smart Digital City using real-time urban data, Sustainable Cities and Society, 600-606.

Resilience Alliance (2012). Resilience. Retrieved 05 15, 2020, from Resilience Alliance, https://www.resalliance.org/resilience.

Reveiu, A., \& Arghir, D.-C. (2020). Mining Social Media to Identify the Immediate Impact of COVID-19 Pandemic on the Romanian Retailers: Early Findings. $6^{\text {th }}$ BASIQ International Conference on New Trends in Sustainable Business and Consumption, 1225-1232, Messina, Italy, Bucharest: ASE.

Rockfeller Foundation Arup. (2015). What is Urban Resilience?, Retrieved 05 15, 2020, from 100 Resilient Cities, http://100resilientcities.org/resources/\#section-1.

Rose, A. (2007). Economic resilience to natural and man-made disasters: Multidisciplinary origins and contextual dimensions, Environmental Hazards, 7(4), 383-398.

Sabou, G., Zota, R., \& Maiorescu, I. (2019). Transforming Bucharest into a Smart City, New Trends in Sustainable Business and Consumption, Bari, Editura ASE.

Shah, S.A., Dursun Zafer, S., M. Mazhar, R., Sufian, H., Sadok Ben, Y., \& Dirk, D. (2019, 06 04). Towards Disaster Resilient Smart Cities: Can Internet of Things and Big Data Analytics Be the Game Changers, Special Section on Urban Computing and Intelligence, 1-7.

Shah, S., Şeker, D., \& Demirel, H. (2017, 01). A Framework for Enhancing Real-time Social Media Data to Improve Disaster Management Process, Advances in Cartography and GIScience, $1-4$.

The Urban China Initiative (2017). UCI Launch 2016 Urban Sustainability Index (USI) Report, Retrieved 2020, from http://www.urbanchinainitiative.org/en/content/details_19_62344 .html.

UNDRR (2019). Quick Risk Estimation (QRE). Retrieved 11 10, 2020, from https://www.unisdr. org/campaign/resilientcities/toolkit/article/quick-risk-estimation-qre.

UN-HABITAT (2018, 02). City Resilience Profiling Tool. UN-HABITAT for a Better Urban Future, p. 13, Retrieved from UN-HABITAT.

UNISDR (2015). Disaster Resilience Scorecard for Cities, Retrieved 2020, from https://www. unisdr.org/campaign/resilientcities/toolkit/article/disaster-resilience-scorecard-for-cities.

United Nations Economic Commission for Europe (2016). Shaping smarter and more sustainable cities: UNECE and ITU launch the United for Smart Sustainable Cities global initiative, Retrieved 2020, from https://www.unece.org/info/media/presscurrent-press-h/housingand-land-management/2016/shaping-smarter-and-more-sustainable-cities-unece-and-itulaunch-the-united-for-smart-sustainable-cities-global-initiative/doc.html. 
United Nations Office for Disaster Risk Reduction (2009). UNISDR Terminologyon Disaster Risk Reduction, International Strategy for Disaster Reduction, 23-24.

URBAN RESILIENCE HUB (2018). What is Urban Resilience, Retrieved 05 15, 2020, from https://urbanresiliencehub.org/what-is-urban-resilience/.

WCCD (2018, 04 27). The New ISO Standard for Resilient Cities Indicators:Opportunities for City and Expert Input, World Council on City Data, 6-17.

World Health Organization (2018). Managing epidemics - Key facts about major deadly diseases, Geneva, World Health Organization.

WorldBank (2018). Urban population (\% of total population) - European Union, Retrieved 0201 , 2021, from The World Bank: https://data.worldbank.org/indicator/SP.URB.TOTL.IN.ZS? locations $=E U$.

Zeng, Y., Xiao, R., \& Li, X. (2013). A resilience approach to symbiosis networks of ecoindustrial parks based on cascading failure model, Mathematical Problems in Engineering 2013, 1-11. 